\title{
Democratização do direito à educação básica no Brasil: algumas ponderações
}

\author{
Democratization of the right to basic education in Brazil: \\ some considerations
}

\section{Democratización del derecho a la educación básica en Brasil: algunas consideraciones}

\author{
Cristiane Machado* \\ ORCID: https://orcid.org/0000-0002-3522-4018
}

\author{
Edson Francisco de Andrade ${ }^{\star \star}$ \\ ORCID: https://orcid.org/0000-0002-7577-898X
}

\begin{abstract}
Resumo: O presente artigo tem como objetivo analisar as injunções da legislação educacional no movimento de democratização do direito à educação no Brasil. À luz da literatura da área, concebe-se a democracia e a ação colaborativa como fundamentos basilares tanto à garantia de direitos aos cidadãos, quanto à efetivação de incumbências por parte do Poder Público. Aborda-se, inicialmente, o advento da educação básica como nova configuração organizativa das etapas e modalidades de ensino obrigatórias no país. Em seguida, analisa-se os dispositivos legais que modificam, especificamente, o Título III da Lei de Diretrizes e Bases da Educação Nacional - LDBEN, no 9.394/1996, Do Direito à Educação e Do Dever de Educar. Os resultados do estudo reconhecem a expansão e diversificação da oferta da educação básica como construto favorável à garantia do direito à educação. Foi possível também inferir que a delimitação da obrigatoriedade e da gratuidade do ensino, ao período dos 04 aos 17 anos de idade, conforme consta na letra da lei, ao mesmo tempo em que estabelece o interstício ideal para a efetivação Do Direito à Educação, também oferece margem interpretativa para eventual flexibilização Do Dever de Educar por parte do Poder Público. Com efeito, a defesa da educação como direito humano fundamental, além de demandar o cumprimento da incumbência Estatal, constitui, sobremaneira, corresponsabilidade a ser protagonizada pela sociedade civil organizada.
\end{abstract}

Palavras-chave: LDBEN/1996; Direito à educação; Dever de educar; Democratização do ensino.

\begin{abstract}
This article aims to analyze the injunctions of educational legislation in the movement to democratize the right to education in Brazil. In the light of the literature in the area, democracy and collaborative action are conceived as basic foundations both in guaranteeing citizens' rights and in carrying out tasks on the part of the government. Initially, the advent of basic education is approached as a new organizational configuration of the stages and modalities of compulsory education in the country. Then, the legal provisions that specifically modify Title III of the Law of Directives and Bases of Education are analyzed National - LDBEN, no 9.394 / 1996, From the Right to Education and the Duty to Educate. The results of the study recognize the expansion and diversification of the offer of basic education as a construct favorable to guaranteeing the right to education. It was also possible to infer that the delimitation of mandatory and free education, from 4 to 17 years of age, as stated in the letter of the law, while establishing the ideal interstice for the realization of the Right to Education, also it offers an interpretive margin for eventual flexibility of the
\end{abstract}

\footnotetext{
* Docente no Departamento de Políticas, Administração e Sistemas Educacionais - DEPASE - na Faculdade de Educação da Universidade Estadual de Campinas - UNICAMP. Vice-coordenadora do Laboratório de Gestão Educacional - LAGE. Doutora em Educação pela Faculdade de Educação da USP - Universidade de São Paulo (2003), Mestre em Educação pela Faculdade de Educação da UNICAMP - Universidade Estadual de Campinas (1995). E-mail: crimacha@unicamp.br

** Doutor em Educação. Docente no Departamento de Administração Escolar e Planejamento Educacional - DAEPE e no Programa de Pós-Graduação em Educação no Centro de Educação da Universidade Federal de Pernambuco UFPE. Pesquisador de Pós-doutorado da UNICAMP (2020-2021). E-mail:edsonfranciscodeandrade@gmail.com.
} 
Duty to Educate by the Public Pow- er. Indeed, the defense of education as a fundamental human right, in addition to demanding compliance with the State's mandate, is, above all, co-responsibility to be played by organized civil society.

Keywords: LDBEN / 1996; Right to education; Duty to educate; Democratization of education

Resumen: Este artículo tiene como objetivo analizar los mandatos de la legislación educativa en el movimiento para democratizar el derecho a la educación en Brasil. A la luz de la literatura en el área, la democracia y la acción colaborativa se conciben como pilares básicos tanto en la garantía de los derechos ciudadanos como en el desempeño de las tareas de gobierno. Inicialmente se aborda el advenimiento de la educación básica como una nueva configuración organizativa de las etapas y modalidades de la educación obligatoria en el país, luego se analizan las disposiciones legales que modifican específicamente el Título III de la Ley de Directrices y Bases de la Educación. Nacional - LDBEN, oo 9.394 / 1996, Del derecho a la educación y el de- ber de educar. Los resultados del estudio reconocen la expansión y diversificación de la oferta de educación básica como un constructo favorable para garantizar el derecho a la educación. También se pudo inferir que la delimitación de la educación obligatoria y gratuita, de los 4 a los 17 años, como se establece en la letra de la ley, al tiempo que se establece el intersticio ideal para la realización del Derecho a la Educación, también oferece un margen interpretativo para una eventual flexibilización del Deber de Educar por parte del Poder Público. En efecto, la defensa de la educación como derecho humano fundamental, además de exigir el cumplimiento del mandato del Estado, es, ante todo, una corresponsabilidad de la sociedad civil organizada.

Palabras clave: LDBEN / 1996; Derecho a la educación; Deber de educar; Democratización de la educación

\section{INTRODUÇÃO}

Após longos 21 anos de Ditadura Militar no Brasil, o movimento em prol da redemocratização que marcara os anos 1980 no país focou uma de suas frentes prioritárias de ação na reinstituição das bases legais que fizessem jus à nova realidade de funcionamento das instituições públicas e entidades sociais e sindicais que se buscava naquele momento histórico. Conforme observou Cury (2008, p.297), “o ordenamento jurídico, movido por essa onda contestatória e esperançosa, teria que incorporar conceitos novos, abstratos, que dessem forma à nova substância nascente".

O que estava em curso era um processo de ruptura com a ordem existente, razão pela qual a convocação de uma constituinte tornara-se imprescindível e urgente. $O$ fato é que a nova ordem que se buscava instituir precisava do amparo de uma Carta Magna que respaldasse a luta a ser travada em defesa por uma cidadania aberta a todos. "É dessa inspiração, declarada e garantida na Constituição, que a educação escolar é proclamada direito. Dela se espera a abertura, além de si, para outras dimensões da cidadania e da petição de novos direitos" (CURY, 2008, p.297).

Há de se reconhecer que o mesmo ímpeto que movia a reivindicação por uma Lei Fundamental essencialmente cidadã para o país, também impregnava o pleito por uma educação escolar pública, gratuita e laica, mas também comprometida com o preparo para o exercício da cidadania. Como bem sintetizou Saviani (2013a, p.216), "se os anos de 1980 foram classificados, do ponto de vista econômico, como a "década perdida", no campo da educação estes anos se configuraram como uma década de importantes ganhos" (grifo do autor).

Se na Constituição de 1967, tida como a Consolidação do Regime Militar, o direito à educação era restrito aos primeiros quatro anos de escolarização, uma vez que o ensino oficial ulterior a esta etapa era gratuito apenas para quantos, demonstrando efetivo aproveitamento, provassem falta ou insuficiência de recursos (BRASIL, 1967), na 
Constituição cidadã de 1988 logrou-se o êxito de assumir a educação como direito de todos e dever do Estado e da família, constituindo-se, por conseguinte, um marco histórico para o processo de democratização da escolarização básica no país.

É justo o reconhecimento da relevância desse novo marco legal como condição objetiva que resguarda formalmente a educação como direito fundamental e inegável aos cidadãos. Contudo, "no Brasil, a constituição do direito à educação nos textos legais, especialmente no que diz respeito à gratuidade e à obrigatoriedade, é marcada por uma trajetória sinuosa e errática que alterna avanços e retrocessos, refletindo as transformações sociais, políticas e econômicas do país" (MACHADO; GANZELI, 2018, p.52). Essa assertiva dos autores realça o movimento contínuo de avanço, mas também de eventual destituição de direitos no campo educacional, razão pela qual também se faz importante a permanente observância das constantes reescritas do próprio arcabouço legal.

Em sintonia com esse entendimento, o presente artigo tem como objetivo analisar as injunções da legislação educacional no movimento de democratização do direito à educação no Brasil. Para tanto, aborda-se, inicialmente, o advento da educação básica como nova configuração organizativa das etapas e modalidades de ensino obrigatórias no país. Em seguida, analisa-se os dispositivos legais que modificam, especificamente, o Título III da Lei de Diretrizes e Bases da Educação Nacional - LDBEN, oo 9.394/1996, Do Direito à Educação e Do Dever de Educar.

Em essência, tece-se ponderações sobre o que se infere da Lei da Educação a respeito da expectativa de democratização da educação básica nas tramas que esta lei cria ao delimitar a obrigatoriedade do ensino ao período dos 04 aos 17 anos de idade, oferecendo margem interpretativa para eventual flexibilização Do Dever de Educar por parte do Poder Público.

\section{O DIREITO À EDUCAÇÃO NO CONTEXTO DA REDEMOCRATIZAÇÃo NO BRASIL}

A Constituição Federal de 1988, que inscreveu o direito à educação como o primeiro direito social (CF/1988, Art. 6º) da população brasileira, foi o ápice de uma morosa e claudicante trajetória histórica de fechamento dos terríveis anos de chumbo da ditadura militar (1964-1985) e de reabertura dos processos democráticos no país.

Embora o início do projeto de abertura lenta e gradual do regime autoritário tenha se dado a partir do ano de 1974, no governo Geisel, foi na década de 1980 que a mobilização de diversos segmentos ligados à educação, com ampla e organizada participação popular, arregimentou poder político para enfrentar o processo de luta pela retomada da democracia no país. Mobilização que, ao somar força com outros atores empenhados no encerramento da ditadura militar, redundou na instalação da Assembleia Nacional Constituinte (19871988) com o objetivo de elaborar a nova Constituição que daria os contornos da redemocratização da sociedade. 
Os debates em torno da Constituinte foram eivados de disputas, na maioria das vezes, dissonantes e, em muitos casos, antagônicas. Vale rememorar que a situação política do país no período era bastante frágil, especialmente, no que diz respeito ao governo de José Sarney, primeiro presidente civil depois de 21 anos de ditadura militar. Indicado como vice na chapa vitoriosa no Colégio Eleitoral em 1985, Sarney assumiu após uma repentina doença que levou Tancredo Neves, presidente eleito, ao falecimento. Kinzo (2001, p. 07) explica os fatores que marcaram essa fragilidade e tornaram 0 governo suscetível a pressões de diferentes grupos políticos:

Sarney tomou posse sem um plano de governo propriamente dito e com um sério déficit em legitimidade: uma figura política marcada por anos de vínculos com os militares, que assumia o poder sem o respaldo das urnas e que não era das fileiras do partido que esperava desta vez governar, o PMDB.

Nesse contexto político vulnerável, a Constituição de 1988 consagrou os princípios democráticos de abertura política, estabelecendo direitos sociais e criando mecanismos de ampliação de participação popular com o objetivo de consolidar um Estado Democrático de Direito, ainda no 'por vir', mas sem alterar as estruturas dominantes existentes, arraigadas desde sempre na sociedade. Para Neves (1999, p. 99), o texto constitucional promulgado expressou uma tentativa de contemplar as "profundas mudanças ocorridas em nosso país na economia, nas relações de poder e nas relações sociais globais, nos últimos 20 anos, introduzindo temas, redefinindo papéis, incorporando às instituições sociais segmentos historicamente marginalizados, sem, no entanto, alterar substantivamente as relações sociais vigentes".

No campo da educação, os embates na Constituinte emergiram em razão dos interesses e concepções divergentes entre o setor do ensino privado e os defensores da escola pública, que polarizaram as disputas em inúmeras questões, notadamente, com maior centralidade, em relação à destinação dos recursos públicos. O conflito girava em torno da definição constitucional se o financiamento público deveria ser destinado exclusivamente para o ensino público ou se os mesmos recursos poderiam financiar, também, escolas particulares. De um lado, o grupo que defendia a destinação de recursos públicos somente para o ensino público se aglutinava no Fórum de Educação na Constituinte em Defesa do Ensino Público e Gratuito e era composto por professores, pesquisadores, especialistas da educação e estudantes universitários, de outro, no grupo do setor privado, encontravam-se os segmentos leigo ou confessional e empresarial ou comunitário (PINHEIRO, 1991).

As disputas entre esses dois fortes grupos duraram meses e, cada um a seu modo, exercia pressão sobre os deputados e senadores na Assembleia Nacional Constituinte na defesa de propostas constitucionais antagônicas. O texto final aprovado para a Constituição refletiu a negociação possível da correlação de forças daquele momento histórico, que foi de perdas e ganhos para os defensores da escola pública. Sobre o tema, Saviani (2013a) ressalta que, se é possível apontar conquistas para o grupo dos defensores da escola pública é, também, necessário reconhecer que as vitórias do setor das escolas 
particulares foram ainda maiores.

Isto porque, se os primeiros garantiram a gratuidade do ensino público em todos os níveis; o piso salarial profissional com ingresso somente mediante concurso público e regime jurídico único para o magistério da União; a gestão democrática do ensino público; a autonomia universitária; a definição da educação como direito público subjetivo e a manutenção da vinculação orçamentária com a ampliação do percentual da União, os segundos asseguraram o ensino religioso no ensino fundamental; o repasse de verbas públicas para as instituições filantrópicas, comunitárias e confessionais; o apoio financeiro do Poder Público à pesquisa e extensão nas universidades particulares; a não aplicação do princípio da gestão democrática, plano de carreira, piso salarial e concursos de ingresso para o magistério das instituições particulares (SAVIANI, 2013a, p. 215).

Apesar dessa constatação, há um consenso de que a Constituição Federal de 1988 consolidou avanços democráticos expressivos, especialmente na área da educação, sobretudo em relação à criação de mecanismos de fortalecimento da cidadania, o que possibilitou sua alcunha de 'Constituição Cidadã'.

$\mathrm{O}$ direito à educação é inscrito como o primeiro dos direitos sociais no texto constitucional (CF/1988, Art. 6o), sendo seguido pelos direitos à saúde, alimentação, trabalho, moradia, transporte, lazer, segurança, previdência social, proteção à maternidade e à infância e assistência. De acordo com Cury (2002, p. 260):

O direito à educação parte do reconhecimento de que o saber sistemático é mais do que uma importante herança cultural. Como parte da herança cultural, o cidadão torna-se capaz de se apossar de padrões cognitivos e formativos pelos quais se tem maiores possibilidades de participar dos destinos de sua sociedade e colaborar na sua transformação. Ter o domínio de conhecimentos sistemáticos é também um patamar sine qua non a fim de poder alargar o campo e o horizonte desses e de novos conhecimentos.

O artigo 205 do texto constitucional, além de declarar que a educação é direito de todos e dever do Estado e da família, estabeleceu que ela deve ser "promovida e incentivada com a colaboração da sociedade, visando ao pleno desenvolvimento da pessoa, seu preparo para o exercício da cidadania e sua qualificação para o trabalho" (CF/1988, Art. 205), frisando o direito à educação como condição de cidadania e dever do Estado e da família. Ao estreitar o vínculo entre o direito à educação e o preparo do exercício da cida- dania, o preceito constitucional fixou a educação como condição indissociável da vida em sociedade, Para Goergen (2013, p. 740), mais que isso, a Constituição determinou que o direito à educação tem status privilegiado em relação aos demais direitos sociais, uma vez que se configura como "condição inarredável para o exercício da cidadania, constituindo-se, portanto, em direito fundamental de todos os seres humanos". Para o autor, a cidadania relaciona-se à competência de intervenção tanto nos espaços privados quanto nos assuntos públicos de ordem política e a educação é a condição para a conquista dessa competência, "só essa dupla capacidade e habilidade leva o sujeito a ultrapassar o umbral da simples e formal posse de direitos e alcançar o que se pode chamar de cidadania ativa, ou seja, a verdadeira participação no modelo democrático" (GOERGEN, 2013, p. 732). Sa- viani (2013b, p. 745), assevera que a 
educação é prerrogativa para o exercício de todos os direitos, "para além de se constituir em determinado tipo de direito [...] configura-se como condição necessária, ainda que não suficiente, para o exercício de todos os direitos, sejam eles civis, políticos, sociais, econômicos ou de qualquer outra" e, neste sentido, corrobora com a assertiva de Goergen (2013).

A Constituição Federal, além de explicitar as obrigações do Estado mediante o cumprimento do direito à educação, determinou que "o acesso ao ensino obrigatório e gratuito é direito público subjetivo" (Artigo 208, inciso VII, $\S 1^{\circ}$ ), preceito que, embora defendido como necessário desde 1933 pelo renomado jurista Pontes de Miranda (FIGUEIREDO; LINS JUNIOR, 2018, p. 198), somente foi incorporado à legislação maior nos estertores do século XX. Nessa mesma linha, Cury (2008) chama a atenção para o fato de que foi necessário percorrer um longo caminho até a coroação da educação como direito público subjetivo na Carta Magna brasileira, evidenciando a longa historicidade presente na proclamação constitucional deste direito.

[...] da instrução própria das primeiras letras no Império, reservada apenas aos cidadãos, ao ensino primário de quatro anos nos estados da Velha República, do ensino primário obrigatório e gratuito na Constituição de 1934 à sua extensão para oito anos em 1967, derrubando a barreira dos exames de admissão, chegamos ao direito público subjetivo (CURY, 2008, p. 295).

Importa acentuar que a garantia constitucional do direito à educação como direito público subjetivo, assim como os embates já citados anteriormente, foi construída com intensas disputas entre diferentes atores, instituições e partidos políticos, tanto no Congresso Nacional quanto na sociedade civil. Moraes (2018), em tese de doutoramento, analisa os percalços dos diferentes interesses em conflito no campo educacional durante a constituinte e a polissemia que envolvia o direito à educação frente aos diferentes grupos e movimentos sociais, manifestada principalmente nas comissões e subcomissões da Assembleia Nacional Constituinte até a configuração final do texto constitucional.

Atribuir o caráter de direito público subjetivo ao direito à educação é importante porque é esse dispositivo que possibilita a garantia do cumprimento do próprio direito, tanto em relação ao dever do Estado no seu oferecimento como, também, em relação à legitimidade de instrumentos de luta da sociedade pelo direito. Duarte (2004, p. 113) assim define direito público subjetivo:

Trata-se de uma capacidade reconhecida ao indivíduo em decorrência de sua posição especial como membro da comunidade, que se materializa no poder de colocar em movimento normas jurídicas no interesse individual. Em outras palavras, o direito público subjetivo confere ao indivíduo a possibilidade de transformar a norma geral e abstrata contida num determinado ordenamento jurídico em algo que possua como próprio. A maneira de fazê-lo é acionando as normas jurídicas (direito objetivo) e transformando-as em seu direito (direito subjetivo).

Vale sublinhar que muito embora o texto final da Constituição Federal de 1988 tenha refletido a vitória daqueles que defendiam a necessidade de expressar o direito à educação como direito público subjetivo na Carta Magna, os diferentes interesses e visões sobre esse conceito não desapareceram com a redação final da Constituição e permanecem até os 
dias atuais, manifestos nas legislações infraconstitucionais, bem como nas políticas públicas educacionais, demonstrando que as disputas ideológicas presentes nos debates para a elaboração da Carta Magna se fizeram e se fazem presentes de diferentes formas, ao longo dos trinta anos de sua vigência.

Ainda com o objetivo de fazer valer a prerrogativa da definição de direito público subjetivo, a Constituição de 1988 criou mecanismos para garantir a efetivação do direito à educação mediante o dever do Estado em efetivar tal direito, trazendo um aspecto inovador em relação a todas as constituições anteriores existentes no país, conforme Oliveira (1999, p. 65):

O que é inovador, para além de uma maior explicitação dos direitos e de uma maior precisão jurídica, evidenciada pela redação, é a previsão dos mecanismos capazes de garantir os direitos anteriormente enunciados, estes sim, verdadeira novidade. São eles o mandado de segurança coletivo, o mandado de injunção e a ação civil pública.

É indiscutível que a promulgação da Constituição Federal de 1988 alçou o debate sobre o direito à educação a um patamar nunca antes alcançado no país, seja pela valorização da importância do preceito, seja pelo detalhamento das responsabilidades governamentais, seja pela criação de mecanismos jurídicos para a efetivação de tal direito, entretanto, depreende-se que os autores apontam um distanciamento entre a previsão do direito à educação na Constituição Federal e sua materialização na sociedade brasileira, ou seja, estabelecer a educação como direito social não garante sua efetividade (MACHADO; GANZELI, 2018). Nesse sentido, a Constituição criou algumas ferramentas que deveriam funcionar como uma espécie de 'rede de ajuda' no aprimoramento e fortalecimento do direito à educação, no entanto, dada a inexistência de regulamentação e de cumprimento em alguns casos, essas ferramentas não cumprem os papéis para os quais foram pensadas.

Em que pese essa lacuna específica na legislação, ainda assim, cabe colocar em relevo que a LDBEN/1996 estabelece a garantia de padrão de qualidade como um dos princípios com base nos quais o ensino deve ser ministrado em todo o país (Art. $3^{\circ}$, IX). Por óbvio, esse dispositivo legal respalda o direito das cidadãs e dos cidadãos a um padrão de qualidade equivalente em sua escolarização, a ser efetivado, indistintamente, em cada ente da federação. Para além do merecido reconhecimento por essa conquista formal de direito, sua efetivação tem sido historicamente relegada a último plano. A esse respeito, cabe salientar a já conhecida desigualdade inter e intrarregional na oferta educacional, "decorrente da assimetria entre as condições econômicas dos entes federados e a distribuição de competências previstas constitucionalmente, que indica o que cabe a cada um realizar no tocante ao provimento da educação para a população" (OLIVEIRA; SOUSA, 2010, p.13).

É justamente em consideração a esse quadro que defendemos a imprescindibilidade de uma rede de ajuda, respaldada na própria legislação vigente no país, que potencialize a garantia do direito à educação básica com o mesmo padrão de qualidade em todo o território nacional. Com efeito, "uma das características centrais dos países que 
apresentam uma educação de qualidade é a redução das desigualdades entre as escolas" (PINTO, 2015, p.104).

Tal rede que aqui advogamos requer, inadiavelmente, a efetivação de três ferramentas já concebidas legalmente. São elas: o Regime de Colaboração entre a União, os Estados, o Distrito Federal e os Municípios (CF/1988, Art. 1ํ, 18, 23, 29, 30 e 211), bem como a instituição do Sistema Nacional de Educação - SNE e o cumprimento do Plano Nacional de Educação - PNE (CF/1988, Art. 214). A ajuda que se vislumbra com a ativação em rede dessas ferramentas decorre justamente da possibilidade de "repartição das responsabilidades entre os entes federativos, todos voltados para o mesmo objetivo de assegurar o direito de cada brasileiro, provendo uma educação com o mesmo padrão de qualidade a toda a população" (SAVIANI, 2013b, p.755).

Efetivamente, o Regime de Colaboração estabelecido pela CF/1988 determinou que as esferas do Poder Público atuassem de forma colaborativa e cooperativa no atendimento à educação em todos os níveis, visando repartir responsabilidades sem perder a perspectiva de Estado nacional. Nesse sentido, o ato de colaborar pressupõe o compartilhamento de com- petências na coordenação, implementação e avaliação das políticas educacionais, com o intento de garantir equalização da qualidade do atendimento das demandas educacionais no país (ANDRADE, 2014).

As outras duas ferramentas estabelecidas no artigo 214 da CF/1988, que são o PNE e o SNE, têm por perspectiva a organização e gestão de um projeto nacional de educação que resguarde a organicidade das políticas e dos programas (ANDRADE, 2014). O PNE (2014-2024), o segundo criado no país, o primeiro teve vigência de 2001 a 2011, foi aprovado pela Lei no 13.005 de 25 de junho de 2014, contendo 14 artigos, 20 metas e 256 estratégias. Sua execução está ancorada, fundamentalmente, na ação do Poder Público, especialmente o federal, que possui função redistributiva, o que não vem acontecendo há muito tempo.

De acordo com o texto constitucional, o objetivo do PNE é:

Articular o sistema nacional de educação em regime de colaboração e definir diretrizes, objetivos, metas e estratégias de implementação para assegurar a manutenção e desenvolvimento do ensino em seus diversos níveis, etapas e modalidades por meio de ações integradas dos poderes públicos das diferentes esferas federativas que conduzam a:

I- erradicação do analfabetismo;

II- universalização do atendimento escolar;

III - melhoria da qualidade do ensino;

IV- formação para o trabalho;

V - promoção humanística, científica e tecnológica do País.

VI - estabelecimento de meta de aplicação de recursos públicos em educação como proporção do produto interno bruto (CF/1988, Art. 214).

A relevância desse dispositivo, inserido na Carta Magna de 1988, reside no reconhecimento do papel do PNE como instrumento articulador e viabilizador do atendimento sistêmico das demandas educacionais no país. De maneira efetiva,

Num país dotado de um Sistema Nacional de Educação funcionando em plenitude, as metas do Plano Nacional de Educação derivam dos Princípios Educacionais fixados na Constituição e são formuladas à luz do diagnóstico do Sistema de 
Educação, visando a suprir suas necessidades. Isto significa que a realização das metas enunciadas no Plano tem como objetivo aproximar o Sistema da realidade desejável, expressa nos Princípios Educacionais. Consequentemente, se o desenvolvimento do Sistema Educacional é condicionado pelo Plano de Educação no âmbito do qual se definem as metas e os recursos com os quais o Sistema opera, a viabilidade do Plano de Educação depende do Sistema Educacional, pois é nele e por ele que as metas previstas poderão se tornar realidade (SAVIANI, 2013a, p.210).

O fato é que a ausência de um SNE, que perdura até os dias atuais no país, fragiliza a materialização do Regime de Colaboração, especialmente, no tocante ao cumprimento de planos articulados de educação. Desta feita, embora tenhamos o princípio da colaboração como recomendação legal para relação intergovernamental na República Federativa do Brasil, essa expectativa ainda não saiu do papel, apesar de sua previsão legal (PNE, Art. 13) e dos esforços e luta dos profissionais da educação. Sabe-se, no entanto, que a consolidação do SNE poderia contribuir na construção de uma educação nacional articulada, possibilitando avançar na igualdade de condições no oferecimento da educação e potencializando a qualidade do ensino.

As disputas não cessaram com a promulgação da Constituição Federal em 05 de outubro de 1988, elas migraram para a elaboração da lei que tem o objetivo de regulamentar os princípios constitucionais, a Lei de Diretrizes e Bases da Educação Nacional.

\section{ADVENTO DA EDUCAÇÃo BÁsicA E A RECONFIGURAÇÃo DA OBRIGATORIEDADE DO ENSINO}

A expressão educação básica foi incorporada ao vocabulário corrente nos debates do campo educacional com o intuito de se referir ao que se considera básico no processo de escolarização. Cury (2008) explica que, etimologicamente, "base", donde procede a expressão "básica", assume a acepção de etapas conjugadas sob um só todo. Conforme assertiva do autor, "Base provém do grego básis,eós e corresponde, ao mesmo tempo, a um substantivo: pedestal, fundação, e a um verbo: andar, pôr em marcha, avançar" (CURY, 2008. p.294, grifos do autor).

Cabe realçar que esse entendimento do que deve se constituir base na educação escolar ainda não correspondia, necessariamente, ao sentido de conjunto de etapas de ensino formalmente concebidas e delimitadas em legislação própria da educação. A rigor, em sua versão original, a CF/1988 estabeleceu que apenas o ensino fundamental constituía etapa obrigatória e gratuita, a ser assumida como dever do Estado com a educação (Art. 208), ainda que, neste artigo da Constituição, constasse a indicação de progressiva extensão da obrigatoriedade e gratuidade ao ensino médio, de atendimento educacional especializado às pessoas com deficiência, assim como de atendimento em creche e pré-escola às crianças de zero a seis anos de idade (BRASIL, 1988a). O fato é que nem a pré-escola, nem o ensino médio foram inicialmente concebidos, na Carta Magna, como etapas basila- res da educação nacional. 
$\mathrm{Na}$ realidade, a expressão ensino fundamental, tal qual fora assumida no texto original da CF/1988, guardava coerência com o que se concebe por base da educação escolar. Este é o sentido que se infere do disposto no Art. 210, que preconizava a fixação de conteúdos mínimos para o ensino fundamental com o propósito de assegurar o que esta Lei Maior nomeou como formação básica comum e respeito aos valores culturais e artísticos, nacionais e regionais (BRASIL, 1988a).

Pode-se considerar que a expressão "Da Educação Fundamental", estampada no Título IV do Projeto de Lei no 1.258/1988, que marcara o início do longo trâmite da atual Lei de Diretrizes e Bases da Educação Nacional, no Congresso Nacional, além de substituir o termo ensino por educação, demarcou uma importante diferença com a expressão "ensino fundamental" cunhada pela CF/1988, uma vez que, para esse projeto de LDBEN, a préescola e o então ensino de $2^{\circ}$ grau também integravam o que se queria instituir como base da educação no país.

Esse é o entendimento que se infere do Projeto de Lei oํ 1.258/1988, ao preconizar, em seu Art. 16, que "a educação fundamental abrange o período correspondente à faixa etária dos zero aos dezessete anos e tem por objetivo geral o desenvolvimento omnilateral dos educandos de modo a torná-los aptos a participar ativamente da sociedade" (BRASIL, 1988b). Havia, aqui, estreita relação entre o sentido que se buscava atribuir ao termo "fundamental" e a defesa pela ampliação do direito à educação que marcara os movimentos sociais no contexto da redemocratização do país. Tratava-se de um pleito que requisitava, enfaticamente, expansão das etapas de ensino, conforme ficava explícito no Art. 17 do Projeto, onde constava que "a educação fundamental compreende três etapas: educação anterior ao $1^{\circ} \mathrm{grau}$, de zero a seis anos; educação de $1^{\circ} \mathrm{grau}$, dos sete aos catorze anos; e educação de $2^{\circ}$ grau, dos quinze aos dezessete anos" (BRASIL, 1988b).

Faz-se pertinente observar que, apenas na seção "justificação", portanto, após o conjunto dos artigos que compunha esse primeiro projeto de LDBEN, a expressão educação básica é incorporada ao texto. Não obstante a relevância dessa expressão no texto inicial da Lei da Educação, cabe ponderar que seu sentido ainda não correspondia ao que foi consagrado, finalmente, na LDBEN/1996. Na realidade, foram os movimentos nacionais e internacionais em defesa do direito à educação, no início da década de 1990, que impulsionaram o debate sobre esse tema, constituindo-se, inclusive, referencial para novas agendas de políticas públicas.

O exemplo emblemático desses movimentos é a Conferência Mundial de Educação para Todos, realizada em Jomtien, na Tailândia, em março de 1990. Já no título da declaração, onde foram sistematizadas as proposições desse evento, explicita-se a satisfação das necessidades básicas de aprendizagem como ideário assumido no conjunto daquele documento. À luz desse entendimento, emerge a concepção de que "a educação básica é mais do que uma finalidade em si mesma. Ela é a base para a aprendizagem e o desenvolvimento humano permanentes, sobre a qual os países podem construir, sistematicamente, níveis e tipos mais adiantados de educação e capacitação" (UNESCO, 1998, p.1). Com efeito, o que se reivindicava neste documento era a garantia de 
uma base educacional que transcendesse a demarcação estrita de etapas de ensino com finalidade em si mesma. Para tanto, o que estava em causa era a garantia de uma formação escolar suficientemente consistente para potencializar a aprendizagem e o desenvolvimento humano permanentes.

Faz-se pertinente considerar que a Conferência de Jomtien constituiu-se um marco do amplo debate sobre o direito à educação que se desencadeou no mundo a partir de 1990. Esta já era uma bandeira a muito tempo erguida por movimentos sociais em diversos países, a exemplo do Brasil, mas a incorporação dessa causa como pleito central da Declaração de Jomtien teve relevância indubitável para a consagração desse tema como pauta inadiável da elaboração de políticas educacionais, dentre elas, a reformulação da legislação específica para o setor de educação nos países que enviaram seus representantes para a Conferência.

Para justificar os pleitos indissociáveis por educação básica e pelo direito à educação, os conferencistas evidenciaram o fato de que após décadas de vigência da Declaração Universal dos Direitos Humanos (1948), quando as nações do mundo afirmaram que "toda pessoa tem direito à educação", o que se constatava naquele ano de 1990 era um quadro de persistente relegação desse direito e até sua regressão nos países com maior desigualdade social. Como se evidenciou já no preâmbulo da Declaração redigida ao final do evento, em março de 1990, mais de 100 milhões de crianças não tinham acesso ao ensino primário; mais de 960 milhões de adultos eram analfabetos; mais de um terço dos adultos do mundo não tinham acesso ao conhecimento impresso, às novas habilidades e tecnologias; e mais de 100 milhões de crianças e incontáveis adultos não conseguiam concluir o ciclo básico, e outros milhões, apesar de concluí-lo, não conseguiam adquirir conhecimentos e habilidades essenciais (UNESCO, 1998).

Esse quadro de evidente negação do direito à educação que marcava o início dos anos 1990 deu o tom de que os esforços a serem empreendidos no âmbito de cada Estado nacional não poderiam se circunscrever a uma etapa elementar de formação escolar. Foi com esse entendimento que Gadotti (1991, p.1) considerou que "uma das primeiras consequências da Conferência de Jomtien foi deslocar o eixo do debate educacional, principalmente no chamado Terceiro Mundo, do tema da "alfabetização" para o tema da "educação básica"” (grifos do autor).

Em resposta a esse pleito, a realização de reformas passou a ser um movimento comum no setor de educação ao longo dos anos 1990. Conforme observou Cury (2007, p.484), "hoje, praticamente, não há país no mundo que não garanta, em seus textos legais, o direito de acesso, permanência e sucesso de seus cidadãos à educação escolar básica". No caso brasileiro, a Constituição Federal, sancionada no final da década de 1980, não incorporara o compromisso com a garantia do direito à educação básica, uma vez que essa expressão nem consta no texto da Lei, conforme já realçamos. Não obstante essa lacuna na Lei Maior, o pleito foi imediatamente incorporado à terceira versão do projeto da atual LDBEN que, à época, tramitava no Congresso Nacional.

Aqui cabe uma breve nota sobre o fato de que no período de 29 de novembro de 
1988, quando teve início o trâmite do primeiro projeto da LDBEN, até o mês de maio de 1990, a educação básica ainda não havia sido assumida, pelos congressistas, como tema a ser contemplado nos debates e no texto da lei. Foi precisamente no período de 09 de maio a 28 de junho de 1990 que esse tema entrou definitivamente na pauta, tendo sido finalmente incorporado ao Projeto de Lei, substitutivo Jorge Hage, em 28 de junho de 1990 (SAVIANI, 2016).

Cabe realçar que o Capítulo VI dessa versão do Projeto de LDBEN, intitulado "Da educação escolar e seus níveis", explicitava ineditamente, em seu Art. 26, que a educação escolar seria organizada na forma de Educação Básica e Educação Superior. É também a partir dessa versão do Projeto que a universalização da educação básica, em todos os seus níveis e modalidades, é reconhecida como dever do Estado. Tratava-se, portanto, de um dispositivo legal que imputava ao Poder Público a incumbência da oferta e manutenção da educação infantil, do ensino fundamental e do ensino médio, que haviam também sido introduzidos como níveis de ensino.

Além do consistente detalhamento dos níveis e modalidades de ensino, esse substitutivo acrescentou ao projeto da LDBEN um sentido peculiar ao que deveria ser compreendido como direito básico à educação a ser garantido na e pela organização escolar. A própria expressão educação básica torna-se sinônimo de uma concepção ampliada da escolarização, que "incluiu entre seus objetivos a expansão do enfoque em educação" (VIEIRA, 2007, p.65), uma vez que suas etapas são entendidas como conjugadas sob um só todo, portanto, fazendo jus ao sentido etimológico do termo "base". Por isso mesmo, essa expressão foi recebida como "um conceito mais do que inovador para um país que, por séculos, negou, de modo elitista e seletivo, a seus cidadãos, o direito ao conhecimento pela ação sistemática da organização escolar" (CURY, 2008. p.294).

Em verdade, esse conceito novo agrega, simultaneamente, um propósito à escolarização e um reconhecimento do direito a uma formação escolar que assegure perspectivas de progressos aos cidadãos, especialmente no tocante ao gozo dos direitos sociais que thes são inerentes. Desde então, assumiu-se, em essência, o disposto no Art. 22 da LDBEN/1996, em vigor, ao enunciar que "a educação básica tem por finalidades desenvolver o educando, assegurar-Ihe a formação comum indispensável para o exercício da cidadania e fornecer-lhe meios para progredir no trabalho e em estudos posteriores" (BRASIL, 1996a).

A concepção de formação básica a ser alcançada, necessariamente, por meio do desenvolvimento articulado das três etapas de ensino, assumidas como fase basilar da organização escolar, exigiu a fixação de âmbitos de atuação prioritária para cada ente de poder federado, constituindo-se, assim, um importante referencial para a materialização do necessário e inadiável regime de colaboração que deve ser firmado entre a União, os Estados, o Distrito Federal e os Municípios, com o intento de que o conjunto da educação básica seja efetivado. 


\subsection{A obrigatoriedade do Ensino no Brasil: da CF/1988 à LDBEN/1996}

Desde setembro de 1996, portanto, antes de a LDBEN ser sancionada em dezembro daquele mesmo ano, a Emenda Constitucional no 14/1996 fixou as atuais incumbências dos Municípios e Estados com a garantia dos níveis que compõem a educação básica. Efetivamente, o $\S 2^{\circ}$ do Art. 211 da CF/1988 estabelece que "os Municípios atuarão prioritariamente no ensino fundamental e na educação infantil". Já o $\S$ $3^{\circ}$ desse mesmo artigo diz que "os Estados e o Distrito Federal atuarão prioritariamente no ensino fundamental e no ensino médio" (BRASIL, 1996b).

Faz-se pertinente reconhecer que essa alteração feita no texto constitucional criou condições favoráveis para a consagração, no texto da LDBEN/1996, da educação infantil, do ensino fundamental e do ensino médio como níveis que compõem a educação básica no país. Contudo, em face de neste ano (1996) a CF/1988 estabelecer apenas o ensino fundamental como etapa de ensino obrigatória, o texto legal que tratava do dever do Poder Público com a garantia do direito à educação dos brasileiros, na prática, relegou a segundo plano o compromisso com a oferta das demais etapas de ensino formalmente previstas na Constituição, uma vez que os Municípios e os Estados, incumbidos da oferta da educação infantil e do ensino médio, respectivamente, puderam justificar que, sem as condições financeiras necessárias para irem além do que a própria lei havia estabelecido como única etapa obrigatória, deveriam eximir-se da obrigatoriedade com os demais níveis de ensino. Ressalte-se que, apesar de o texto constitucional dispor que "a União, os Estados, o Distrito Federal e os Municípios organizarão em regime de colaboração seus sistemas de ensino" (CF/1988, Art. 211), essa atuação colaborativa se referia apenas à universalização do ensino obrigatório. Essa delimitação de atendimento educacional foi notabilizada por meio da Lei oㅜ 9.424/1996, que regulamentou o Fundo de Manutenção e Desenvolvimento do Ensino Fundamental e de Valorização do Magistério - FUNDEF, em 26 de dezembro de 1996 (BRASIL, 1996c), três dias após a LDBEN/1996 ter sido sancionada.

Como o próprio Caput da lei explicitava, o FUNDEF foi cotejado com o propósito de levar a efeito a focalização dos investimentos públicos apenas no ensino fundamental. Apesar da indiscutível relevância desse fundo contábil para o crescimento da oferta do ensino obrigatório no país, o que também se viu foi o Governo Federal eximir-se da colaboração necessária com os demais entes federados, responsáveis diretos pelo volume das matrículas na educação infantil e no ensino médio.

Como sintetizou, pertinentemente, Fernandes (2009, p.27),

\footnotetext{
$\mathrm{Na}$ prática, o Fundef acelerou o processo de municipalização do ensino fundamental e contribuiu para a melhoria dos salários ínfimos dos professores, principalmente do Nordeste. Entretanto, des-incentivou a abertura de creches e pré-escolas pelas prefeituras e provocou o desfinanciamento do ensino médio pelos Estados.
}

De fato, a segunda metade dos anos 1990 foi marcada, no setor educacional, pela intensa transferência de matrículas, especialmente dos Estados para o âmbito da 
administração Municipal. Contudo, a colaboração da União restou insuficiente até mesmo com a promoção do ensino fundamental, foco do fundo contábil, visto que "a origem estadual e municipal quase total dos recursos do FUNDEF e a insignificância da complementação federal levaram críticos do FUNDEF a afirmar que o Governo Federal estaria com o FUNDEF fazendo "cortesia com o chapéu dos Estados e Municípios"" (DAVIES, 2003, p.160, grifos do autor).

Em face desse evidente descompromisso histórico da União com o conjunto dos níveis básicos de ensino, fez-se notar a urgência de uma reforma na lei que tornasse compulsória a colaboração entre os entes federados na promoção do conjunto dos níveis de ensino no país. Cabe reconhecer que um passo importante nessa direção foi dado com a conversão do FUNDEF em Fundo de Manutenção e Desenvolvimento da Educação Básica e de Valorização dos Profissionais da Educação - FUNDEB, por meio da lei no 11.494/2007 (BRASIL, 2007).

Ao incorporar a educação infantil e o ensino médio, o novo fundo contábil foi recebido como um contributo à garantia do direito ao conjunto da educação básica, justamente por ter superado a focalização dos investimentos financeiros em apenas uma das etapas de ensino. Essa positividade no acolhimento do FUNDEB era de fato cabível'1. No entanto, logo se constatou que se tratava mesmo de apenas um primeiro passo, afinal,

Ainda que represente um ganho em relação à situação anterior, uma vez que prevê a distribuição de recursos para toda a educação básica, o FUNDEB equaciona de maneira muito limitada dois outros problemas importantes. De um lado, o do aumento do gasto total em educação básica no país, e de outro a ação mais decidida da União na redução da desigualdade entre os estados. Assim sendo, ainda que distribua melhor os recursos para a educação básica, permanece em dívida com dois grandes problemas: o do montante a ser investido em educação pela União e sua ação mais decidida na redução da desigualdade entre os entes federados (OLIVEIRA, 2007, p.122).

Sendo assim, se por um lado é justo que se reconheça o devido crédito ao legislador por instituir, por meio do FUNDEB, uma nova Era ao financiamento da educação básica, por outro lado, a expectativa de avanço na efetivação da colaboração entre os entes federados e, principalmente, de maior aporte financeiro por parte da União não foi suficientemente atendida, sobretudo, porque os $10 \%$ que constituem a parcela do Governo Federal na composição do Fundo tem sido, comprovadamente, diminuta, portanto, aquém do mínimo necessário para constituir-se uma contribuição decisiva em favor do enfretamento à histórica e persistente desigualdade entre os entes federados, tema amplamente abordado na literatura da área educacional (GOUVEIA; SOUZA, 2015; PINTO, 2015; ANDRADE, 2013; PINTO; ALVES, 2011; OLIVEIRA, 2007), entre outros².

Faz-se importante ressaltar que, mesmo com a previsão de distribuição de recursos para toda a educação básica, a institucionalização do FUNDEB, em 2007, ocorreu na vigência do texto constitucional que ainda mantinha apenas o ensino fundamental como nível obrigatório de ensino. Portanto, o alinhamento da nova versão do fundo contábil à concepção da educação básica como um conjunto integrado de etapas de ensino constitui-se um fato importante, sobretudo, porque trouxe à tona a urgência de se redefinir 
a amplitude da obrigatoriedade do ensino e, por consequência, a ampliação do dever do Estado com sua oferta.

Com a nova política de financiamento, tem-se o fato que se precisava para recolocar, no parlamento, o pleito pela redefinição das incumbências obrigatórias dos entes federativos com o que o próprio Estado brasileiro já havia reconhecido como etapas básicas de ensino inegáveis à sua população. Conforme síntese apropriada de Farenzena (2010, p.205), "a ideia subjacente é de que todos devem ter acesso à educação de base, significando, de outra parte, que seletividades na oferta educacional, em qualquer das etapas, negam os direitos de cidadania e sonegam o desenvolvimento e a formação prometidos nos fins da educação básica".

O enfrentamento à sonegação da plena formação básica, como realçou a autora, requereu a consecução de um novo texto constitucional que, além de ratificar âmbitos de atuação prioritária de cada ente federado, avançasse no tocante regulamentação do regime de colaboração entre a União, os Estados, o Distrito Federal e os Municípios, em favor do efetivo cumprimento solidário com o acesso e permanência dos cidadãos à educação básica (SAVIANI, 2013b).

4 O DEVER DE EDUCAR: atribuições do estado, da sociedade e da família

A defesa da educação básica como direito social tem sido historicamente acompanhada da reivindicação pelo cumprimento do dever de educar a ser assumido tanto pelo Estado, quanto por entidades sociais e pela própria família. Com efeito, "a delimitação de um nível da educação como básica tem consequências no direito à educação mais alargado, e de um dever do Estado, incluindo a oferta de vagas e de condições de qualidade que permitam o acesso, a permanência e a conclusão das etapas da escolaridade básica". (FARENZENA, 2010, p.205).

A Declaração de Jomtien (UNESCO, 1998), que já reconhecemos o crédito de ter difundido a concepção de escolarização básica e sua indispensabilidade nas agendas de políticas públicas pelos Estados nacionais, fez ecoar o entendimento de que,

Um compromisso efetivo para superar as disparidades educacionais deve ser assumido. Os grupos excluídos - os pobres: os meninos e meninas de rua ou trabalhadores; as populações das periferias urbanas e zonas rurais os nômades e os trabalhadores migrantes; os povos indígenas; as minorias étnicas, raciais e linguísticas: os refugiados; os deslocados pela guerra; e os povos submetidos a um regime de ocupação - não devem sofrer qualquer tipo de discriminação no acesso às oportunidades educacionais. (UNESCO, 1998, p.4).

1 "Para se ter uma ideia da importância do FUNDEB para a educação municipal no país, dados dos balanços financeiros de 5.050 municípios do ano de 2008 mostram que os impostos arrecadados pela fazenda municipal representam menos de $5 \%$ da receita total do orçamento das prefeituras em $65 \%$ dos municípios brasileiros e menos de $10 \%$ do total dos recursos auferidos pelo tesouro municipal em 87\% deles (PINTO; ALVES, 2011, p.607).

2 A Emenda Constitucional 108/2020, promulgada pelo Senado Federal em 26 de agosto de 2020, determina que o FUNDEB seja instituído em caráter permanente em cada Estado, aumenta a complementação de recursos pela União e assegura a participação da sociedade no planejamento das políticas sociais (Fonte: Agência Senado, em 26/08/2020). Espera-se importante repercussão desta EC em favor da garantia do direito à educação, a conferir na execução orçamentária a partir de 2021. 
Referindo-se ao contexto brasileiro, conforme também já tratamos nesse artigo, o compromisso assumido pelo Estado, por meio da LDBEN/1996, além de ter ficado aquém do que foi delineado como educação básica pela própria Lei da Educação, foi igualmente restritivo no que concerne ao enfretamento das disparidades educacionais explicitadas pela Unesco (1998). Apesar da evidente necessidade de uma ação conjunta dos entes federados, em face do complexo desafio para o adequado provimento do conjunto das etapas e modalidades de ensino que compunha a organização escolar brasileira, o que prevaleceu, de fato, foi o descompromisso especialmente da União, ente que detém maior volume de recursos financeiros, com a conversão da expectativa do direito à educação básica em obrigatoriedade de sua oferta com qualidade social, sobretudo para os segmentos mais desfavorecidos socioeconomicamente.

Com a promulgação da Emenda Constitucional no 59/2009 (BRASIL, 2009), esse quadro foi significativamente alterado em face justamente da ampliação da obrigatoriedade do ensino no país. Esse pleito histórico foi, formalmente, atendido por meio da nova redação dada ao Inciso I do Art. 208 da Constituição, que tornou obrigatória e gratuita toda a educação básica. Essa emenda à Constituição, além de manter o ensino fundamental sob a responsabilidade compartilhada de Estados e Municípios, fez valer, finalmente, tanto a incumbência do ente Municipal com a oferta da educação infantil, quanto a incumbência do ente estadual com a oferta do ensino médio (BRASIL, 2009). De acordo com Pinto (2010, p.214), "é importante destacar que o Brasil, com a EC ํㅜ 59, ao elevar de nove para 14 anos o número de anos de ensino obrigatório, estará posicionado apenas atrás do Chile (que mantém 16 anos de ensino obrigatório) neste quesito, entre todos os países do mundo".

Outro contributo igualmente importante da EC no 59/2009, em favor da efetivação do direito à educação básica, é a explicitação da necessidade de compartilhamento de responsabilidades entre as três esferas administrativas, em face da nova amplitude do dever do Estado com a educação. A esse respeito, faz-se pertinente reconhecer a relevância da alteração no Art. $211, \S 4^{\circ}$, da Carta Magna, ao definir que os entes federados deverão estabelecer formas de colaboração, de modo a assegurar a universalização do ensino obrigatório. A principal forma de viabilização da colaboração foi inserida no texto da própria emenda à Constituição, ao assumir o plano nacional de educação, de duração decenal, com o objetivo de articular o sistema nacional de educação para assegurar a manutenção e desenvolvimento do ensino em seus diversos níveis, etapas e modalidades, conforme consta no Art. 214 da CF/1988 (BRASIL, 2009).

Concebendo-se que "todo sistema deve subordinar-se a um critério que presida, regule e ordene a sistematização" (SANDER, 1993, p.350), a concepção do Plano Nacional de Educação como articulador do Sistema Nacional de Educação (SNE) constituise dispositivo constitucional fundante para a consecução de formas de colaboração entre a União, os Estados, o Distrito Federal e os Municípios como ação necessariamente planejada e sintonizada com a intencionalidade inerente à gestão de um sistema.

Com efeito, 
A consagração da noção de sistema nacional de educação no texto legal pode abrir caminho para a construção de uma escola comum, extensiva a todo o território nacional, unificada pelos mesmos objetivos, organizada sob normas também comuns e regida pelo mesmo padrão de qualidade (SAVIANI, 2016, p.71).

Conforme fica evidente na assertiva de Saviani, o que está em causa é a garantia do direito a uma escola que seja, nacionalmente, regida pelo mesmo padrão de qualidade. Considerando-se o fato de que, a partir da EC no 59/2009, esse direito passa a ser extensivo ao conjunto dos níveis e modalidades de ensino da educação básica, torna-se oportuno discutir as implicações da nova redação da Constituição na LDBEN/1996.

\subsection{Atualidade do dever do Estado com a Educação Básica}

É justo reconhecer que, com a EC nำ59/2009, a educação básica é ratificada definitivamente como direito dos cidadãos e como dever dos entes federativos. Não obstante a relevância desse fato, cabe considerar que, a partir da vigência dessa emenda à Constituição, a delimitação do que passa a valer como etapas obrigatórias de ensino no país tem suscitado um debate profícuo, especialmente sobre o fato de que, na nova redação constitucional (Art. 208, Inciso I), apesar de constar plausível redefinição nas incumbências do Poder Público com o provimento da educação básica obrigatória e gratuita, tem-se a definição de que apenas as crianças e jovens que se encontram no intervalo etário dos 4 aos 17 anos de idade estão efetivamente obrigadas a frequentar a escola. Faz-se importante realçar que, com essa alteração na Lei, não há mais obrigatoriedade de conclusão de pelo menos uma etapa de ensino, como era previsto no texto constitucional anterior, que estabelecia o ensino fundamental como etapa obrigatória, inclusive para os que a ele não tivessem acesso na idade própria.

Ressalte-se que esse mesmo artigo da Constituição, quando se refere aos possíveis beneficiários da educação básica que estão fora desse marco etário (4 aos 17 anos), diz que será "assegurada inclusive sua oferta gratuita para todos os que a ela não tiveram acesso na idade própria” (Art. 208, Inciso I). Não por esquecimento, o termo obrigatório não aparece nesse trecho do artigo, ficando apenas o dever de oferta gratuita das etapas da educação básica pelo Poder Público. Sendo assim,

Para os que frequentarem essas etapas da educação básica, mas com idade acima do limite constitucional, é assegurado o direito ao acesso gratuito e o dever do Estado em fornecer as condições de oferta gratuita, mas não se trata de uma obrigação do jovem ou do adulto concluí-las. (PINTO, 2010, p.213).

É oportuno considerar que tanto o avanço que podemos creditar a EC ㄲo 59/2009, no tocante a ampliação do dever do Estado com a oferta gratuita da educação básica, assim como o seu recuo em não garantir obrigatoriedade da conclusão de qualquer das etapas da escolarização básica, não tiveram efeito imediato na vida das pessoas. Na realidade, 0 Art. $6^{\circ}$ dessa EC estabeleceu que "o disposto no Inciso I do art. 208 da Constituição Federal deverá ser implementado progressivamente, até 2016, nos termos do Plano 
Nacional de Educação, com apoio técnico e financeiro da União". De maneira efetiva, essa demanda foi contemplada na Lei no 12.796/2013 (BRASIL, 2013), que tratou a questão referente à obrigatoriedade $\mathrm{e}$ à gratuidade da educação básica com maior aprofundamento.

O fato é que a Lei no 12.796/2013 alterou a LDBEN/1996, cabendo aqui destacar, especialmente, a redefinição do dever do Estado com a educação escolar pública, vigente nos dias atuais (2020). De acordo com a nova redação dada ao Art. 4º, Inciso I, da Lei da Educação, o Estado fica incumbido da garantia de educação básica obrigatória e gratuita dos 4 aos 17 anos de idade, organizada na forma de pré-escola, ensino fundamental e ensino médio. Observe-se que, ao delimitar a pré-escola (4 a 5 anos de idade) como etapa inicial, apenas parte da educação infantil é reconhecida como etapa integrante do que a Lei passa a conceber como educação básica obrigatória ${ }^{3}$.

Essa obrigatoriedade parcial que foi reservada à educação infantil no texto da Lei pode ser compreendida como um passo atrás em relação ao que historicamente foi defendido como dever a ser assumido pelo Poder Público, principalmente se considerarmos que já na primeira versão do Projeto de Lei que resultou na presente LDBEN havia a proposição da educação anterior ao $1^{\circ}$ grau, de 0 a 6 anos, como primeira etapa do que se compreendia como Educação Fundamental (SAVIANI, 2016).

Cabe também salientar que a etapa pré-escolar, que constitui a parte obrigatória da educação infantil, quando não vivenciada na idade indicada no Art. 4 da LDBEN (4 a 5 anos), não poderá ser recuperada, uma vez que, aos que não concluírem a educação básica obrigatória na idade própria, a Lei garante apenas acesso público e gratuito aos ensinos fundamental e médio. Nesses termos, apesar de formalmente o pré-escolar integrar a fase basilar e obrigatória da formação escolar, não há qualquer garantia legal aos que, por motivos alheios a sua vontade, não puderem exercer esse direito na idade desejada. Trata-se, portanto, de uma etapa formativa passível de ser dispensada, como que esta não tivesse, necessariamente, conexão com as demais etapas subsequentes. consequência, do dever do Estado com a oferta dessa modalidade de ensino, na perspectiva da educação inclusiva.

De forma objetiva, a Lei oㅜ 12.796/2013 instituiu um complemento substancial à LDBEN/1996 (Art. 4ํ, III), que, além da manutenção do atendimento educacional especializado gratuito aos educandos com deficiência, a Lei da Educação passou a resguardar o atendimento às pessoas com transtornos globais do desenvolvimento e altas habilidades ou superdotação, transversal a todos os níveis, etapas e modalidades, preferencialmente na rede regular de ensino.

\footnotetext{
3 Em que pese o Art. 29 da LDBEN definir toda a Educação Infantil como primeira etapa da educação básica, assim como o disposto no Inciso II do Art. $4^{\circ}$ dessa Lei, que menciona a ofertada de educação gratuita às crianças de até 5 anos de idade.
}

4 O Grupo de Trabalho foi constituído por pesquisadores com reconhecido conhecimento acadêmico científico sobre Educação Especial no país. Ver Portaria do MEC n. 555/2007, prorrogada pela Portaria no 948/2007. Disponível em: http://portal.mec.gov.br/arquivos/pdf/politicaeducespecial.pdf 
Considerando-se que "os Transtornos Globais do Desenvolvimento (TGD) referemse a um grupo de transtornos do neurodesenvolvimento caracterizados por condições que surgerem precocemente no desenvolvimento da criança, geralmente antes da idade escolar" (PIAZENTIN, MESSIAS e PACHECO, 2017), a garantia do atendimento educacional às crianças com TGD é, particularmente, imprescindível, uma vez que

\begin{abstract}
A inclusão escolar tem início na educação infantil, onde se desenvolvem as bases necessárias para a construção do conhecimento e seu desenvolvimento global. Nessa etapa, o lúdico, o acesso às formas diferenciadas de comunicação, a riqueza de estímulos nos aspectos físicos, emocionais, cognitivos, psicomotores e sociais e a convivência com as diferenças favorecem as relações interpessoais, o respeito e a valorização da criança. Do nascimento aos três anos, o atendimento educacional especializado se expressa por meio de serviços de intervenção precoce que objetivam otimizar o processo de desenvolvimento e aprendizagem em interface com os serviços de saúde e assistência social (BRASIL, 2008, p.16).
\end{abstract}

Há de se convir que, em se tratando de crianças com TGD, os primeiros anos da educação infantil são essenciais para o desenvolvimento das bases necessárias para a construção do conhecimento e seu desenvolvimento global. Por isso mesmo, em que pese a não obrigatoriedade de matrícula da criança até completar 4 anos de idade, conforme já mencionamos, a reivindicação da garantia do direito à educação a esse grupo etário precisa ser encampada pelos pais ou responsáveis, que passam também a ocupar, no âmbito da LDBEN, uma atribuição fundamental no processo de universalização da educação básica.

\title{
4.2 O dever da sociedade e da família com a garantia do Direito à Educação Básica
}

A concepção de que a efetivação do direito à educação, além de um dever do Estado, constitui, fundamentalmente, um bem inalienável de cada cidadã e de cada cidadão foi formalmente assumida por meio do Art. 208, Inciso VII, $\S 1^{\circ}$ da Constituição Federal de 1988, ao considerar que "o acesso ao ensino obrigatório e gratuito é direito público subjetivo". Tratava-se, objetivamente, de garantir o ensino fundamental, única etapa obrigatória de ensino no momento em que esta Carta Magna foi sancionada. Para fazer valer esse preceito constitucional, fez-se notável a necessidade do reconhecimento desse direito pelo próprio sujeito e seus familiares, mas também o envolvimento da sociedade na vigilância e reivindicação de sua efetivação.

Pode-se considerar que esse dispositivo legal, que concebe a garantia do direito à educação como compromisso efetivamente de todos, foi adequadamente incorporado ao texto da LDBEN/1996, quando preservou a essência do ensino obrigatório como direito público subjetivo e ainda acresceu, no Art. $5^{\circ}$ de sua versão original, a possibilidade de cidadãos, associações, organizações sindicais e o Ministério Público reivindicar a garantia do ensino obrigatório às pessoas que, por algum motivo, inclusive por impedimento da família ou de outrem, estivessem fora da escola.

Esse tema recebeu novo tratamento no âmbito da Lei $n^{0}$ 12.796/2013. Em essência, 
esta lei alterou o Art. 5 da LDBEN/1996 para dispor que "o acesso à educação básica obrigatória é direito público subjetivo, podendo qualquer cidadão, grupo de cidadãos, associação comunitária, organização sindical, entidade de classe ou outra legalmente constituída e, ainda, o Ministério Público, acionar o Poder Público para exigi-lo" (BRASIL, 2013). A princípio, parece digno de enaltecimento o fato de agora não apenas o ensino fundamental, mas toda a educação básica passa a ser exigível como direito público subjetivo (Duarte $(2004)^{5}$.

Contudo, o texto da lei requer a devida atenção para que se perceba que não se trata de um direito extensivo ao conjunto da educação básica. Na realidade, essa é uma garantia circunscrita apenas às pessoas com idade entre 4 a 17 anos. Em verdade, nem as crianças em idade de vivenciar os anos iniciais da educação infantil, nem os jovens e adultos que não cursarem ou não concluírem o ensino fundamental e/ou o ensino médio, no intervalo etário definido pela lei, têm resguardado seu direito público subjetivo à educação escolar. De forma objetiva, esse artigo da LDBEN torna inexigível, a não ser pelo próprio aluno, a efetivação da matrícula para todos os que não concluíram a educação básica na idade própria.

Faz-se oportuno ponderar que o Estado tem, na forma da lei, o dever de ofertar gratuitamente as etapas da educação básica, inclusive, para os que não puderem cursá-la na idade própria. Para tanto, a LDBEN/1996 (Art. 5ํㅗ § $1^{\circ}$ ) estabelece que o Poder Público, na esfera de sua competência federativa, deverá: recensear anualmente as crianças e adolescentes em idade escolar, bem como os jovens e adultos que não concluíram a educação básica (Inciso I); fazer-Ihes a chamada pública (Inciso II); e zelar, junto aos pais ou respon- sáveis, pela frequência à escola (Inciso III). Mesmo diante dessa evidente responsabilização que a Lei da Educação confere aos entes federados, no $\S 2^{\circ}$ do mesmo Artigo o texto legal trata de explicitar o lugar marginal reservado às pessoas que se encontram fora da idade própria para cursar a educação básica, ao disciplinar que "em todas as esferas administrativas, o Poder Público assegurará em primeiro lugar o acesso ao ensino obrigatório, nos termos deste artigo (Art.5ำ da LDBEN), contemplando em seguida os demais níveis e modalidades de ensino, conforme as prioridades constitucionais e legais".

Sendo assim, o que está em causa é que, para quem está fora da faixa etária de 4 a 17 anos, nem a família, nem a sociedade, nem o Ministério Público podem exigir a matrícula compulsória das crianças, dos jovens ou adultos. Disso se infere que, apenas em condições ideais, em que a criança tiver seu direito de matrícula escolar cumprido na idade própria e, necessariamente, tiver a oportunidade de cursar todas as etapas da educação básica com pleno sucesso, a obrigatoriedade do ensino, prevista em lei, será efetivada. Caso haja retardo no início da escolarização e/ou reprovação ao longo da vivência das séries ou ciclos escolares, ou ainda quando houver abandono ou evasão, nesses casos, não há qualquer garantia de conclusão sequer de uma das etapas da educação básica.

5 Ressalte-se que qualquer das partes mencionadas no caput deste artigo tem legitimidade para peticionar no Poder Judiciário, sendo gratuita e de rito sumário a ação judicial correspondente (LDBEN/1996, Art. 5ํㅗㅇ § 3ํ). 
Considerando-se que a Lei nº 12.796/2013 deu nova redação ao Art. 6ํ da LDBEN para estabelecer que "é dever dos pais ou responsáveis efetuar a matrícula das crianças na educação básica a partir dos 4 anos de idade", o direito da criança iniciar sua trajetória na educação básica, na idade própria, está assegurado, como manda a lei. Nesse caso, apenas em circunstâncias comprovadamente excepcionais pode haver retardo no início de vivência da primeira etapa obrigatória de ensino. Em que pese o fato de a lei desobrigar os pais ou responsáveis quanto a efetivação da matrícula das crianças na primeira parte da educação infantil, merece enaltecimento a garantia que se infere da lei quanto a obrigatoriedade de plena vivência da pré-escola (4 a 5 anos de idade).

A esse respeito, tem-se a favor o disposto na nova redação dada ao Art. 31 da LDBEN/1996, que, dentre as regras comuns de organização da educação infantil, estabelece, em seu Inciso I, que a avaliação, nesta etapa de ensino, deve ser efetivada "mediante acompanhamento e registro do desenvolvimento das crianças, sem o objetivo de promoção, mesmo para o acesso ao ensino fundamental". Sendo assim, além de ter resguardado o direito ao início da escolarização básica na idade ideal, a criança, até os 5 anos de idade, também tem assegurado um percurso escolar livre de eventuais reprovações, visto que o efeito da avaliação da aprendizagem, nessa faixa etária, não deve gerar retenção no percurso escolar.

Na realidade, tanto o cumprimento da escolarização básica por parte das criançase dos jovens entre 4 e 17 anos de idade, portanto, aqueles que devem ser matriculados, obrigatoriamente, quanto o atendimento educacional às pessoas que estão fora desse intervalo etário estabelecido em lei, constituem direitos plenamente reivindicáveis pelo próprio beneficiário direto da escolarização básica, mas também pelos seus familiares. Isto significa dizer que, aos pais ou responsáveis, recai o dever de mobilizar, à luz do próprio arcabouço legal vigente, o cumprimento pleno da escolarização básica de seus filhos.

A esse respeito, faz-se imprescindível fazer valer o direito de "atendimento ao educando, em todas as etapas da educação básica, por meio de programas suplementares de material didático-escolar, transporte, alimentação e assistência à saúde" (Art. 4 , VIII); assim como de "vaga na escola pública de educação infantil ou de ensino fundamental mais próxima de sua residência a toda criança a partir do dia em que completar 4 anos de idade" (Art. $4^{\circ}, \mathrm{X}$ ); e ainda de "atendimento educacional, durante o período de internação, ao aluno da educação básica internado para tratamento de saúde em regime hospitalar ou domiciliar por tempo prolongado, conforme dispuser o Poder Público em regulamento, na esfera de sua competência federativa" (Art. 4ํ- A).

Observe-se que essas garantias da lei não são referidas apenas aos alunos que se encontram na dita idade própria, estabelecida em lei. Quis o legislador que, em todas as etapas da educação básica, tanto o acesso, quanto a gratuidade fossem garantidas pelo Estado. Esse é o entendimento que se infere do título III da LDBEN/1996, inclusive quando garante o "acesso público e gratuito aos ensinos fundamental e médio para todos os que não os concluíram na idade própria" (Art. $4^{\circ}$, IV). 


\section{CONSIDERAÇÕES FINAIS}

Abordamos, ao longo deste artigo, a relevância do advento da educação básica como nova configuração organizativa das etapas e modalidades de ensino no país. $O$ ideário da garantia de uma base educacional à população brasileira colocou em pauta demandas historicamente já apresentadas por segmentos em defesa da educação. A esse respeito, reconhece-se a importância de a Constituição ter resguardado, formalmente, a coexistência do Regime de Colaboração, do PNE e do SNE como ferramentas basilares para o cumprimento do dever do Estado com a oferta gratuita de educação básica.

O avanço na efetivação dessas ferramentas, concebidas neste artigo como potencial 'rede de ajuda', constitui-se um pleito da ordem do dia. Trata-se, pois, de uma natureza de ajuda recíproca a ser, necessariamente, compartilhada entre sistemas de educação das três esferas administrativas, em favor da garantia de um mesmo padrão de qualidade de educação escolar em todo o território nacional (SAVIANI, 2013b). Sobre essa matéria, fazse pertinente reconhecer que a aprovação do PNE (2014-2024), Lei o 13.005/2014 (BRASIL, 2014), em que pese seus limites e condicionantes, expressa a reafirmação mais veemente do direito à escolarização básica do povo brasileiro em estreita sintonia com os avanços formais nessa pauta, viabilizados por meio das reformas à LDBEN/1996.

Com efeito, o PNE (2014-2024), além de ter explicitado o lugar a ser exercido pela União na oferta das etapas da educação básica, também tem o mérito de ter feito reverberar nos Estados, no Distrito Federal e nos Municípios a elaboração de planos de educação com diretrizes, metas e estratégias conectadas às que foram concebidas para 0 âmbito na- cional. Apesar dessa pertinente "consagração da noção de sistema nacional de educação no texto legal" (SAVIANI, 2016, p.71), a conversão de metas planejadas em ações efetivas no chão da escola tem se revelado um processo lento e aquém do que foi formalmente conquistado. Além do descumprimento proposital e escancarado do PNE, há ainda limites que precisam ser enfrentados, a exemplo da reivindicação do direito à educação básica para além do intervalo etário dos 4 aos 17 anos de idade, a fim de que este Plano cumpra a expectativa gerada de "abrir caminho para a construção de uma escola comum, extensiva a todo o território nacional, unificada pelos mesmos objetivos, organizada sob normas também comuns e regida pelo mesmo padrão de qualidade" (SAVIANI, 2016, p.71).

O fato é que a CF/1988, a LDBEN/1996 e o PNE (2014-2024) convergem no entendimento de que o foco do dever do Estado é otimizar a oferta apenas de matrículas obrigatórias. Isto fica evidente, por exemplo, quando a Constituição estabelece que as formas de colaboração cotejadas quando da organização dos sistemas de ensino por cada ente federado tem como propósito assegurar a universalização do ensino obrigatório (CF/1988, Art. 211). Outro exemplo desse fato é que a previsão de distribuição dos recursos públicos tem prioridade assegurada quando destinada "ao atendimento das necessidades do ensino obrigatório, no que se refere a universalização, garantia de padrão de qualidade e equida- de, nos termos do plano nacional de educação" (CF/1988, 
Art. 212, § $\left.3^{\circ}\right)$.

É justo considerar plausível a consecução de toda a educação básica obrigatória como direito público subjetivo. Contudo, é igualmente pertinente ponderar o tom conservador assumido pela LDBEN/1996 quando circunscreve a validade desse direito aos educandos que estejam entre 4 e 17 anos de idade. Ao estabelecer esse marco temporal de vida como o interstício ideal (idade própria) para a efetivação Do Direito à Educação, entende- mos que a lei acaba também oferecendo margem interpretativa para eventual flexibilização Do Dever de Educar por parte do Poder Público. Sendo assim, para além desse dispositivo que institui uma obrigatoriedade limitada ao ensino escolar, é preciso recorrer ao conjunto das injunções da legislação educacional em favor do movimento de democratização do direito à educação. De forma especial, faz-se necessário levar a efeito o cumprimento da escolarização básica garantida, formalmente, aos cidadãos, ao contingenciar a matrícula a partir dos 4 anos de idade e ao conceder acesso gratuito ao ensino fundamental e ao ensi- no médio, a qualquer tempo (LDBEN/1996, Art. $4^{\circ}$ ).

Cabe ressaltar uma das dimensões do direito à educação, garantida na letra da lei, mas aplicável, fundamentalmente, quando pleiteada pela família da criança. Trata-se da inclusão escolar de alunos com deficiência, TGD e altas habilidades/superdotação, contemplada, ineditamente, na LDBEN/1996. Conforme realçamos no desenvolvimento do artigo, o atendimento educacional à pessoa com TGD (autismo, síndromes do espectro do autismo e psicose infantil), bem como aos transtornos funcionais específicos (dislexia, disortografia, disgrafia, discalculia, transtorno de atenção e hiperatividade, entre outros), potencializa o desenvolvimento global do indivíduo, especialmente, quando efetivado nos primeiros anos da criança ( 0 a 3 anos de idade). Nesse caso, a reafirmação do dever do Estado com a oferta gratuita dessa modalidade de ensino, constituindo-se, inclusive compromisso incor- porado ao atual PNE (Meta 4), apesar de sua imprescindibilidade, não é suficiente para transformar a formalidade da lei em direito efetivo.

O que estamos realçando aqui é que o Estado tem a obrigação legal da oferta gratuita, mas não há obrigatoriedade na lei quanto a efetivação da matrícula nessa fase da vida, nem há autorização para que qualquer cidadão, grupo de cidadãos, entidade de classe, nem mesmo o Ministério Público, possa acionar o Poder Público e exigi-lo. Esse é um exemplo apropriado para realçarmos o lugar que deve ser ocupado pela família em defesa do direito à educação, uma vez que a própria criança, nessa tenra idade, ainda não é capaz de fazê-lo. Igualmente importante é o entendimento de que a plena escolarização básica também constitui um direito reivindicável por parte dos próprios jovens e adultos.

A rigor, apenas o jovem ou adulto, titular do direito à educação, com idade superior a 17 anos, pode decidir pelo não cumprimento de uma ou o conjunto das etapas da escolarização básica. Com efeito, o conjunto de dispositivos da LDBEN, especialmente o seu título III, objeto de análise neste artigo, dispõe de garantias que tornam praticamente injustificável a negação do direito à educação básica. Por isso mesmo, a defesa da educação como direito humano fundamental, para além de um compromisso do Estado, constitui, sobremaneira, corresponsabilidade a ser protagonizada pela família e, de forma mais ampla, pela sociedade civil organizada. 


\section{REFERÊNCIAS}

ANDRADE, Edson Francisco de. A gestão sistêmica da educação: do âmbito nacional ao contexto do poder local. Perspectiva, Florianópolis, v. 32, n. 3, p. 1073-1100, set./dez. 2014.

ANDRADE, Edson Francisco. Regime de Colaboração no financiamento da Educação Básica no Brasil: a experiência dos fundos contábeis em foco. Educação, Santa Maria, v. 38, n. 2, p. 389-402, maio/ago. 2013.

BRASIL. Presidência da República. Constituição da República Federativa do Brasil. Brasília. 1967.

BRASIL. Presidência da República. Constituição da República Federativa do Brasil. Brasília. 1988a.

BRASIL. Projeto de Lei n. 1.258, de 1988 (Do Sr. Octávio Elísio). Diário do Congresso Nacional (Seção I). Brasília: Câmara dos Deputados, 1988b.

BRASIL. Lei no 9.394, de 20 de dezembro de 1996. Dispõe sobre as Diretrizes e Bases da Educação Nacional. Presidência da República. 1996a.

BRASIL. Emenda Constitucional no 14/1996. Modifica os artigos 34, 208, 211 e 212 da Constituição Federal e dá nova redação ao art. 60 do Ato das Disposições constitucionais transitórias. Presidência da República. 1996b.

BRASIL. Lei no 9.424, de 24 de dezembro de 1996. Dispõe sobre o Fundo de Manutenção e Desenvolvimento do Ensino Fundamental e de Valorização do Magistério, na forma prevista no art. 60, $\S 7^{\circ}$, do Ato das Disposições Constitucionais Transitórias, e dá outras providências. Presidência da República. 1996c.

BRASIL. Política Nacional de Educação Especial na Perspectiva da Educação Inclusiva. Brasília/DF: MEC/SECADI, 2008.

BRASIL. Emenda constitucional no 59, de 11 de novembro de 2009. Modifica o artigo 76 do Ato das Disposições Constitucionais Transitórias; dá nova redação aos incisos I e VII do Art. 208; dá nova redação ao $\S 4^{\circ}$ do art. 211 e ao $\S 3^{\circ}$ do art. 212 e ao caput do art. 214 . Presidência da República. 2009.

BRASIL. Ministério da Educação. Lei no 11.494/1996. Regulamenta o Fundo de Manutenção e Desenvolvimento da Educação Básica e de Valorização dos Profissionais da Educação - FUNDEB. Diário Oficial da União, Brasília: 21 jun. 2007.

BRASIL. Lei no 12.796, de 4 de abril de 2013. Altera a Lei no 9.394, de 20 de dezembro de 1996, que estabelece as diretrizes e bases da educação nacional, para dispor sobre a formação dos profissionais da educação e dar outras providências. Presidência da República. 2013.

BRASIL. Relatório do 3 ciclo de monitoramento das metas do Plano Nacional de Educação 2020. Brasília: INEP, 2020. 568p. 
CURY, Carlos Roberto Jamil. Direito à educação: direito à igualdade, direito à diferença. Cadernos de Pesquisa, v. 116, n. 116, p. 245-262, julho 2002.

CURY, Carlos Roberto Jamil. A educação básica como direito. Cadernos de Pesquisa, v. 38, n. 134, p. 293-303, agosto 2008.

CURY, Carlos Roberto Jamil. A gestão democrática na escola e o direito à educação. Revista Brasileira de Política e Administração da Educação, v.23, n.3, p. 483-495, set./dez. 2007.

DAVIES, NICHOLAS. Conselhos do FUNDEF: a participação impotente. Ensaio: avaliação, políticas públicas e educacionais. Rio de Janeiro, v. 11, n. 41, out./ dez. p. 502-517, 2003.

DUARTE, Clarice Seixas. Direito público subjetivo e políticas educacionais. Revista São Paulo em Perspectiva, São Paulo, vol. 18, n. 02, p. 113-118, 2004.

FARENZENA, Nalú. A Emenda da obrigatoriedade: mudanças e permanências Revista Retratos da Escola, Brasília, v. 4, n. 7, p. 197-209, jul./dez. 2010.

FERNANDES, Francisco das Chagas. Fundeb como política publica de financiamento da educação básica. Revista Retratos da Escola, Brasília, v.3, n.4, p.23-38, jan/jun.2009.

FIGUEIREDO, Jéssica Antunes; LINS JÚNIOR, George Sarmento. O direito fundamental à educação e sua efetividade no Brasil: uma análise à luz da teoria dos direitos fundamentais de Pontes de Miranda e da Constituição brasileira de 1988. Revista Direitos Sociais e Políticas Públicas (UNIFAFIBE), v. 6, n. 1, p. 195-218, 2018.

GADOTTI, Moacir. Significado e desafio da educação básica. Instituto Paulo Freire, 1991.

GOERGEN, Pedro. A educação como direito de cidadania e responsabilidade do Estado. Educação \& Sociedade, Campinas, v. 34, n. 124, p. 723-742, jul.-set. 2013.

GOUVEIA, Andréa B; SOUZA, Ângelo R. de. A política de fundos em perspectiva histórica: mudanças de concepção da política na transição Fundef e Fundeb. Em Aberto, Brasília, v. 28, n. 93, p. 45-65, jan./jun. 2015.

KINZO, Maira D’Alva G. A democratização brasileira: um balanço do processo político desde a transição. São Paulo em Perspectiva, 15(4) 2001.

MACHADO, Cristiane; GANZELI, Pedro. Gestão educacional e materialização do direito à educação: avanços e entraves. Educar em Revista, Curitiba, Brasil, v. 34, n. 68, p. 49-63, mar./abr. 2018.

MORAES, Viviane Merlim. O direito à educação no campo político brasileiro: disputasideológicas na elaboração da Constituição Federal de 1988. 311 p. Tese (Doutorado em Educação). Faculdade de Educação. Universidade Federal Fluminense, RJ. 2018.

NEVES, Lúcia M. W. Educação e política no Brasil de hoje. 2 ed. São Paulo: Cortez, 1999.

OLIVEIRA, Romualdo Portela de. O Direito à Educação na Constituição Federal de 1988 e seu restabelecimento pelo sistema de Justiça. Revista Brasileira de Educação, no 11, p. 61-74, mai-ago. 1999. 
OLIVEIRA. Romualdo Portela de. O financiamento da educação. In: OLIVEIRA. Romualdo Portela; ADRIÃO. Theresa (Orgs). Gestão, financiamento e direito à educação: análise da constituição federal e da LDB. 3aㅗ ed. São Paulo: Xamã, 2007.

OLIVEIRA, Romualdo Portela de; SOUSA, Sandra Zákia. Introdução. In: OLIVEIRA. R. P.; SANTANA, Wagner (Orgs.). Educação e Federalismo no Brasil: combater as desigualdades, garantir a diversidade. Brasília: UNESCO, 2010. p.13-35.

PINHEIRO, Maria Francisca Sales. O público e o privado na educação brasileira: um conflito na Constituinte (1987-1988). Tese (Doutorado) - Universidade de Brasília, Brasília, 1991.

PINTO, José Marcelino de R. O Fundeb na perspectiva do custo aluno qualidade. Em Aberto, Brasília, v. 28, n. 93, p. 101-117, jan./jun. 2015.

PINTO, José Marcelino de R; ALVES, Thiago. O Impacto Financeiro da Ampliação da Obrigatoriedade Escolar no Contexto do FUNDEB. Educação \& Realidade. 2011, 36(2), 605-624.

PIAZENTIN, Olga Maria Rolim Rodrigues; MESSIAS, Vera Lúcia Fialho Capellini; PACHECO, Ana Paula Moraes Maturana. Variáveis pessoais de professores para o atendimento a alunos com transtorno global do desenvolvimento. Revista Educação Especial. 2017, 30(59), 681-696.

SANDER, Benno. Sistemas e anti-sistemas na educação brasileira. Revista Brasileira de Estudos Pedagógicos: Brasília, v. 74, n. 177, p. 335-370, maio/ago. 1993.

SAVIANI, D. Contribuição à elaboração da LDB: um início de conversa. ANDE, n. 13, p. 5-14, 1988.

SAVIANI, Dermeval. A educação na Constituição Federal de 1988: avanços no texto e sua neutralização no contexto dos 25 anos de vigência. Revista Brasileira de Política e Administração da Educação, Recife, v. 29, n. 2, p. 207-221, maio/ago. 2013a.

SAVIANI, Dermeval. Vicissitudes e perspectivas do direito à educação no Brasil: abordagem histórica e situação atual. Educação \& Sociedade, Campinas, v. 34, n. 124, p. 743-760, jul.-set. $2013 b$.

SAVIANI, Dermeval. A lei da educação: trajetória, limites e perspectivas. Campinas: Autores Associados, 2016.

VIEIRA, Sofia Lerche. Política(s) e Gestão da Educação Básica: revisitando conceitos simples. Revista Brasileira de Política e Administração da Educação. Vol. 23, n. 01, pp. 53-69, jan/abr, 2007.

UNESCO. Declaração mundial sobre Educação para Todos: satisfação das necessidades básicas de aprendizagem - 1990. Unesco, 1998. 